\title{
Kualitas Daging Se i Sapi yang Diproses Menggunakan Buah Belimbing Wuluh (Averrhoa Bilimbi Linn) Kering Matahari
}

\section{Quality of Se'i Beef Meat Processed Using Sun Dried Bilimbi Fruit (Averrhoa Bilimbi Linn)}

\author{
T. R. Zainal*, P. R. Kale, dan G. E. M. Malelak
}

\author{
Program Pascasarjana, Prodi Ilmu Peternakan,Universitas Nusa Cendana \\ Jln. Adisucipto Penfui, Kupang, NTT \\ *Corresponding author: tririzkiezainal@gmail.com
}

\begin{abstract}
This research was conducted to examine the use of sun dried Bilimbi fruit (Averrhoa Bilimbi Linn) on the quality of $s e^{\prime} i$ beef. The method used was an experimental method with a factorial completely randomized design (CRD) consisting of $24 \times 4$ pattern factors consisting of 4 levels of sun dried Bilimbi fruit fruit giving $0 \%$ (control), $1.5 \%$, $3 \%, 4.5 \%(\mathrm{w} / \mathrm{w})$ and 4 factors of storage time of 7 days, 14 days, 21 days and 28 days. The combination of these two factors results in 16 combinations for each treatment consisting of 3 replications, thus obtaining 48 units. The parameters measured in the study were $\mathrm{pH}$, fat oxidation (TBA), antioxidant activity, and total plate count (TPC). Data analysis using ANOVA, if the effect is very significant $(\mathrm{P}<0.01)$, then Duncan further test is carried out to determine the difference between treatments with SPSS 23 software. significant $(\mathrm{P}<0.05)$ on $\mathrm{pH}$, fat oxidation (TBA), antioxidant activity, total plate count (TPC). The level of $4.5 \%$ sun dried Bilimbi fruit gave the highest results on antioxidant activity, and the lowest value was on $\mathrm{pH}$, fat oxidation (TBA) and total plate count (TPC) at a level of $1.5 \%$ to $4.5 \%$ suppresses the rate of fat oxidation (TBA) and total plate count (TPC) at each storage length of days 7, 14, 21 and 28; on the contrary, the value of antioxidant activity tends to increase with increasing fruit levels of Bilimbi fruit sun dried at different storage times.
\end{abstract}

Key words: Bilimbi fruit, se'i, storage time, sun drying.

\begin{abstract}
ABSTRAK
Penelitian ini telah dilakukan untuk mengkaji penggunaan buah belimbing wuluh (Averrhoa Bilimbi Linn) kering matahari terhadap kualitas daging $s e^{\prime} i$ sapi. Metode yang digunakan adalah metode eksperimen dengan desain menggunakan Rancangan Acak Lengkap (RAL) faktorial yang terdiri dari 2 faktor pola $4 \mathrm{x} 4$ yang terdiri dari 4 faktor level pemberian buah belimbing wuluh kering matahari $0 \%$ (kontrol), 1,5\%,3\%, 4,5\% (w/w) dan 4 faktor lama penyimpanan 7 hari, 14 hari, 21 hari dan 28 hari. Kombinasi Kedua faktor ini menghasilkan 16 kombinasi setiap perlakuan terdiri atas 3 ulangan, dengan demikian akan diperoleh 48 unit. Parameter yang diukur dalam penelitian adalah $\mathrm{pH}$, oksidasi lemak (TBA), aktivitas antioksidan, total plate count (TPC). Data analisis menggunakan Anova, apabila berpangaruh sangat nyata $(\mathrm{P}<0,01)$ dilakukan uji lanjut Duncan untuk mengetahui perbedaan diantara perlakuan dengan software SPSS 23. Hasil dari penelitian ini menunjukan bahwa interaksi antara faktor level buah belimbing wuluh kering matahari dan faktor lama penyimpanan berpengaruh nyata $(\mathrm{P}<0,05)$ terhadap $\mathrm{pH}$, oksidasi lemak (TBA), aktivitas antioksidan, total plate count (TPC). Level pemberian buah belimbing wuluh kering matahari 4,5\% memberikan hasil tertinggi pada aktivitas antioksidan, dan nilai terendah pada $\mathrm{pH}$, oksidasi lemak (TBA) dan total plate count (TPC). Pada level 1,5\% sampai 4,5\% menekan laju oksidasi lemak (TBA) dan total plate count (TPC) pada setiap lama penyimpanan hari ke 7, 14, 21 dan 28, sebaliknya pada nilai aktivitas antioksidan cenderung meningkat seiring penambahan level buah belimbing kering matahari pada lama penyimpanan yang berbeda.
\end{abstract}

Kata kunci: Belimbing wuluh, se'i, lama penyimpanan, pengeringan matahari,

\section{PENDAHULUAN}

Pangan adalah segala sesuatu yang berasal dari sumber hayati dan air, baik yang diolah maupun tidak diolah, yang diperuntukkan sebagai makanan atau minuman bagi konsumsi manusia, termasuk bahan tambahan pangan, bahan baku pangan dan bahan lain yang digunakan dalam proses penyiapan, pengolahan, dan pembuatan makanan dan minuman (Peraturan Pemerintah RI nomor 28 tahun, 2004). Semakin meningkatnya kesadaran masyarakat akan pentingnya gizi pangan yang dikonsumsi, maka permintaan akan daging juga semakin meningkat karena daging merupakan bahan pangan sumber protein hewani bagi manusia. Daging sapi masih menjadi pilihan masyarakat untuk dikonsumsi karena nilai gizi yang lengkap. 
Daging sapi memiliki kandungan protein $18,8 \%$, air 66\%, dan lemak 14\% (Departemen Kesehatan RI,1995). Kandungan nutrien daging yaitu protein, lemak, asam lemak tak jenuh dan kolesterol akan menentukan pilihan konsumen. Daging memiliki komposisi gizi yang baik untuk pertumbuhan mikroorganisme, maka daging termasuk bahan makanan yang mudah rusak serta mudah tercemar oleh mikroorganisme perusak (Buckle et al., 1987). Seiring dengan meningkatnya konsumsi daging, semakin banyak pula hasil olahan asal daging yang berkembang dalam kehidupan masyarakat baik daging yang diolah secara tradisional maupun modern.

Se'i adalah salah satu bentuk olahan daging dengan cara pengasapan, menurut Malelak (2010) daging se'i merupakan produk olahan tradisional khas masyarakat Nusa Tenggara Timur (NTT yang memiliki bau, citarasa dan warna yang khas. Daging se'i mengandung protein 15,3\% $19,48 \%$, lemak $3,62 \%$ - 5,98\%, karbohidrat $71,53 \%-75,95 \%$. Proses pengolahan se' $i$ tidak terlalu rumit sehingga dapat dilakukan dengan mudah, pengolahan se' $i$ dimulai dengan mengiris daging secara memanjang sehingga berbentuk seperti seutas tali, diberi garam, bawang putih, ketumbar dan saltpeter, diperam kemudian diasapi. Namun dalam penanganannya se'i mempunyai kelemahan yaitu umur simpan sangat singkat 3-7 hari hal ini yang menyebabkan se'i mudah terkontaminasi oleh mikroorganisme (Hutasoit et al., 2013).

Bahan pangan lokal terutama herbal yang dimiliki Indonesia sangat melimpah namun dalam pemanfaatannya masih tergolong kurang. Salah satu bahan herbal yang ada dimasyarakat adalah buah belimbing wuluh tujuan dari pemberian buah belimbing wuluh dalam pengolahan se'i ialah sebagai bahan pengawet alami. Ashari (1995) menyatakan bahwa kombinasi pengolahan buah belimbing wuluh pada masyarakat masyarakat masih rendah sebagai bumbu dapur, bahan pengawet makanan dan obat batuk tradisional karena buah belimbing wuluh mempunyai rasa yang sangat masam sehingga masyarakat tidak langsung mengkonsumsinya. Buah belimbing wuluh digolongkan sebagai buah yang memiliki aktivitas antioksidan yang bermanfaat bagi kesehatan manusia, karena mengandung vitamin C. Vitamin C merupakan antioksidan yang dapat melindungi sel dari agen penyebab kanker. Senyawa antioksidan dapat menyumbangkan satu atau lebih elektron kepada radikal bebas (Suhartono, 2002).
Beberapa penelitian tentang aktivitas antimikroba belimbing wuluh telah dilakukan, diantaranya penelitian Sulistyani et al. (2017) menunjukan bahwa sari buah belimbing wuluh (Averrhoa bilimbi Linn) pada konsentrasi 20\%, $40 \%, 60 \%, 80 \%$, dan $100 \%$ dapat menghambat pertumbuhan bakteri Staphylococcus aureus pada daging broiler. Penelitian Pradana et al. (2020) menunjukan bahwa perendaman daging kalkun afkir menggunakan sari belimbing wuluh dengan konsentrasi dan lama perendaman yang berbeda berpengaruh terhadap nilai $\mathrm{pH}$ dan WHC, perlakuan terbaik untuk menghasilkan kualitas daging kalkun afkir, dengan memberi sari belimbing wuluh $40 \%$ dan lama perendaman 15 menit.

Untuk mendapatkan buah belimbing wuluh kering perlu menggunakan proses seperti pengeringan. Menurut Pinem (2004) Ada beberapa metode pengeringan yang dapat dilakukan seperti menggunakan oven (oven drying), pengeringan menggunakan panas sinar matahari (solar drying), pengeringan beku (freeze drying), dan lain-lain. Buah belimbing wuluh kering merupakan produk hasil pengolahan yang dapat dilakukan dengan cara pengeringan sehingga dapat disimpan dengan waktu yang lama dan bisa langsung dikonsumsi. Metode pengeringan adalah proses mengeluarkan atau menghilangkan sebagian air dari suatu bahan pangan dengan cara menguapkan sebagian besar kandungan airnya. Air yang dikeluarkan sampai ambang batas dimana mikroba tidak dapat tumbuh dan berkembang sehingga mengurangi rusaknya bahan pangan akibat aktivitas mikroba.

Penelitian ini bertujuan untuk mengetahui pemberian level yang berbeda yang ditambahkan buah belimbing wuluh kering matahari berpengaruh terhadap kualitas se' $i$ dan mengetahui pengaruh pemberian buah belimbing wuluh kering matahari berpengaruh terhadap lama simpan se'i yang dihasilkan.

\section{MATERI DAN METODE}

Bahan yang digunakan dalam penelitian ini adalah daging sapi bali segar umur 1,5-2 tahun dengan skor tubuh 3-4 yang diambil dari otot bagian paha belakang yang dibeli dari Rumah Potong Hewan sebanyak $10 \mathrm{~kg}$, Buah belimbing wuluh segar yang berwarna hijau muda dengan panjang $5-7 \mathrm{~cm}$, belimbing kering matahari, garam dapur $(\mathrm{NaCl})$, saltpeter $\left(\mathrm{KNO}_{3}\right)$, kayu kusambi, daun kusambi, aquades, tissue dan aluminium foil. 


\section{Proses pengeringan matahari (sun drying) belimbing wuluh}

Buah belimbing wuluh segar dibersihkan dan cuci menggunakan aquades agar steril, Belimbing wuluh diiris tipis dengan ketebalan \pm 1 $\mathrm{cm}$ kemudian Irisan buah belimbing wuluh diletakkan diatas loyang serta penjemuran dilakukan di bawah sinar matahari selama 3 hari dengan waktu $8 \mathrm{jam} / \mathrm{hariSetelah}$ mendapat belimbing wuluh kering matahari selanjutnya menghaluskannya dengan menggunakan blender selama 5 menit dengan kecepatan 12.000 -14.000 RPM, Setelah itu dilakukan pengayakan dengan ukuran ayakan 40 mesh, dan didapat bubuk belimbing wuluh kering matahari dan hasilnya disimpan dalam wadah kedap udara.

\section{Prosedur pengolahan $\boldsymbol{s} \boldsymbol{e} \boldsymbol{i}$}

Prosedur pengolahan se'i mengikuti petunjuk Malelak (2010) dengan modifikasi yaitu: Daging sapi segar tanpa lemak sebanyak $10 \mathrm{~kg}$, kemudian dicuci dan ditiriskan. Daging diiris dengan tebal $\pm 2-3 \mathrm{~cm}$, dengan bentuk memanjang (lalolak), campur daging dengan gram $2 \%$ dari berat daging, saltpeter yang sudah dihaluskan $0,01 \%$ atau $100 \mathrm{mg} / \mathrm{kg}$ daging segar, bawang putih $1 \%$ dari berat daging, ketumbar $0,3 \%$ dari berat daging, dicampurkan ke dalam daging sambil dibolak-balik. Buah belimbing wuluh kering ditimbang sesuai level $1,5 \%(1,5 / 100 \times$ berat daging), $3 \%(3 / 100 \times$ berat daging $)$ dan $4,5 \%$ $(4,5 / 100 \times$ berat daging). Masing-masing level buah belimbing wuluh kering matahari dicampurkan ke daging dengan perhitungan sebagai berikut:

- $1,5 \%$ belimbing wuluh dicampur ke daging yang sudah di-lalolak

- $\quad 3 \%$ belimbing wuluh dicampur ke daging yang sudah di- lalolak

- $4,5 \%$ belimbing wuluh dicampur ke daging yang sudah di- lalolak;

Daging dimasukan ke dalam plastic klip dan dilubangi bagian bawah, kemudian diperam di kulkas dengan temperature $4^{\circ} \mathrm{C}$ selama $\pm 12 \mathrm{jam}$, setelah pemeraman daging dikeluarkan dari kulkas dan diasapi menggunakan pemanggang, bagian atas daging ditutupi daun kusambi, se' $i$ yang telah matang diangkat dan didinginkan. Pengambilan sampel untuk pengujian, $\mathrm{pH}$, oksidasi lemak (TBA), aktivitas antioksidan, Total Plate Count masing-masing 100 gram.

\section{Metode Penelitian}

Penelitian ini adalah penelitian eksperimen dan desain eksperimen yang digunakan adalah Rancangan Acak Lengkap (RAL) Pola Faktorial pada metode ini sumber terdiri dari 2 faktor dan diperoleh pola faktorial 4 $\mathrm{x} 4$ sehingga diperoleh 16 kombinasi yang terdiri dari 4 level lama penyimpanan dengan 4 level pemberian buah belimbing wuluh kering. Perlakuan yang terdiri dari dua faktor yakni: lama penyimpanan 7 hari, lama penyimpanan 14 hari, lama penyimpanan 21 hari, lama penyimpanan 28 hari. Level pemberian belimbing wuluh kering. $S e$ ' $i$ tanpa campuran belimbing kering matahari, level pemberian buah belimbing wuluh kering matahari $1,5 \%(\mathrm{w} / \mathrm{w})$, level pemberian buah belimbing wuluh kering matahari $3 \%(\mathrm{w} / \mathrm{w})$, level pemberian buah belimbing wuluh kering matahari $4,5 \%(\mathrm{w} / \mathrm{w})$.

\section{pH}

Analisis $\mathrm{pH}$ menggunakan metode (Kosim, 2015), Sampel se'i 10 gram, se'i dihaluskan dan ditambah aquades, kemudian masukan pH meter, Lakukan beberapa kali pengukuran untuk memperoleh hasil nilai $\mathrm{pH}$ yang akurat, jika melakukan pengukuran $\mathrm{pH}$ dengan sampel yang berbeda, maka sebelum alat $\mathrm{pH}$ meter digunakan, ujung alat $\mathrm{pH}$ meter dikalibrasi terlebih dahulu dengan menggunakan aquades, kemudian dikeringkan dengan tissue. Setelah itu lakukan pengukuran, masukan alat $\mathrm{pH}$ meter ke dalam larutan aquades dan daging selanjutnya bergantian sampai angka yang muncul stabil.

\section{Oksidasi lemak (TBA)}

Analisis Thiobarbituric Acid (TBA) mengguakan metode menurut (Sudarmadji et al., 1997). Penentuan angka TBA dilakuan dengan cara daging se' $i$ ditimbang sebanyak 3 gram, dimasukkan ke dalam waring blander dan ditambahan $50 \mathrm{ml}$ aquades, selanjutnya dipindah ke dalam labu destilasi $1000 \mathrm{ml}$ sambil dicuci dengan 48,5 $\mathrm{ml}$ aquades dan ditambahan $1,5 \mathrm{ml} 4$ N HCl. Selanjutnya, ditambahkan batu didih dan bahan pencegah buih (antifoam) sedikit dan dipasang labu destilat pada alat destilasi. Destilasi dijalankan dengan pemanasan setinggi mungkin sehingga diperoleh destilat sebanyak $50 \mathrm{ml}$ selama pemanasan 10 menit. Destilat yang diperoleh diaduk, disaring dan sebanyak $50 \mathrm{ml}$ dipindahkan ke dalam erlenmeyer yang tertutup dan ditambahkan reagen TBA sebanyak $5 \mathrm{ml}$ (larutan $0,02 \mathrm{M}$ thiobarbituric-acid dalam $90 \%$ asam asetat glasial). Larutan dicampur dalam erlenmeyer 
tertutup dan dimasukkan ke dalam air mendidih selama 35 menit. Tabung reaksi didinginkan dengan air mengalir kemudian diukur absorbansinya pada panjang gelombang $528 \mathrm{~nm}$ dengan larutan blano sebagai titik nol. Angka TBA dihitung dan dinyatakan dalam mgmalonaldehid/kg sampel.

$$
\mathrm{TBA}=\frac{3}{\text { berat sampel }(\text { gram })} \times A(\text { Absorbansi) } 528 \times 7,8
$$

\section{Aktivitas antioksidan}

Analisis Aktivitas antioksidan ditentukan dengan metode DPPH menurut Yen dan Cheng (1994). Timbang sampel 1-2 gram, larutkan menggunakan methanol pada kosentrasi tertentu, diambil 1 larutan induk, dimasukan pada tabung reaksi, tambahkan $1 \mathrm{ml}$ larutan 1,1,2,2 - Diphenyl Picryl Hydrazyl (DPPH), 200 mikro molar, inkubasi pada ruang gelap selama 30 menit, encerkan hingga $5 \mathrm{ml}$ menggunakan methanol, buat blanko ( $1 \mathrm{ml}$ larutan DPPH $+4 \mathrm{ml}$ ethanol) tera pada panjang gelombang $517 \mathrm{Nm}$.

Aktivitas Antioksidan (\%) $=\frac{O D \text { Blangko }- \text { OD }(\text { sampel })}{O D \text { Blangko }} \times 100 \%$

\section{Uji Total Plate Count}

Analisis bakteri mengikuti prosedur (BSN, 2008) analisis total mikroba dilakukan dengan menimbang 25 gram se' $i$ secara aseptis dan dimasukkan kedalam kantong steril dan ditambahkan dengan $225 \mathrm{ml}$ larutan BPW kemudian di stomacher selama 2 menit. Selanjutnya tuangkan larutan BPW sebanyak $9 \mathrm{ml}$ kedalam tabung reaksi steril dan kemudian ditambahkan $1 \mathrm{ml}$ suspensi pengenceran $10^{-1}$ dengan pipet steril ke dalam larutan $9 \mathrm{ml} \mathrm{BPW}$ untuk mendapatkan pengenceran $10^{-2}$. Lakukan pengenceran $10^{-3}, 10^{-4}, 10^{-5}$, dan $10^{-6}$, dengan cara yang sama. Kemudian $1 \mathrm{ml}$ suspensi dari setiap pengenceran dimasukkan ke dalam cawan petri steril. Tuangkan media PCA yang sudah di dinginkan hingga suhu $45^{\circ} \mathrm{C}$ kedalam cawan petri yang telah berisi suspensi dan digerakkan secara hati-hati untuk menyebarkan sel-sel mikroba secara merata, yaitu dengan gerakan seperti angka delapan. Setelah agar membeku, cawan diinkubasi dengan posisi terbalik pada suhu $37^{\circ} \mathrm{C}$ selama $24 \pm 2$ jam. Setelah diinkubasi dihitung jumlah koloni yang tumbuh dengan menggunakan colony counter.

\section{Analisis Data}

Data $\mathrm{pH}$, oksidasi lemak (TBA), aktivitas antioksidan dan Total Plate Count dianalisa menggunakan ragam Analysis of Variance
(ANOVA). Jika hasil analisis ragam menunjukkan adanya perbedaan yang nyata atau sangat nyata maka akan dilanjutkan dengan uji Duncan untuk mengetahui perbedaan diantara perlakuan. Proses analisis menggunakan software SPSS 23.

\section{HASIL DAN PEMBAHASAN}

\section{pH daging}

Rataan nilai $\mathrm{pH}$ daging $s e^{\prime} i$ dapat dilihat pada pada Tabel 1. Hasil analisis statistik menunjukan bahwa penggunaan buah belimbing wuluh kering matahari terhadap kualitas daging $s e^{\prime} i$ tidak berpengaruh nyata $(\mathrm{P}>0,05)$ terhadap $\mathrm{pH}$ daging se'i. Akan tetapi interaksi antara faktor pemberian buah belimbing wuluh kering matahari dan faktor lama penyimpanan sangat mempengaruhi $\mathrm{pH}$ daging se'i $(\mathrm{P}<0,01)$.

Interaksi antara faktor pemberian buah belimbing wuluh kering matahari dan faktor lama penyimpanan menurunkan $\mathrm{pH}$ daging $s e ' i$, pada lama penyimpanan hari ke 14 sampai hari ke 28 terjadi penurunan $\mathrm{pH}$ daging se'i setelah pemberian level $1,5 \%$ buah belimbing wuluh kering matahari, seiring dengan pemberian level $1,5 \%, 3 \%$ dan $4,5 \% \mathrm{pH}$ daging se' $i$ cenderung menurun pada lama penyimpanan.

$\mathrm{Hal}$ ini diduga karena penurunan nilai $\mathrm{pH}$ pada daging se'i disebabkan semakin tinggi pemberian level asam yang diberikan pada daging se'i sehingga mengakibatkan banyaknya jumlah kandungan asam organik yang masuk dalam daging se'i. Jaelani et al. (2016) melaporkan adanya perbedaan $\mathrm{pH}$ pada lama penyimpanan disebabkan oleh kadar glikogen dalam jaringan otot, yang berimbas pada penimbunan asam laktat dalam daging.

Menurut Oktasari et al. (2020) bahwa perendaman daging menggunakan asam-asam organik seperti asam sitrat, asam malat, asam tartrat, asam laktat, mampu menurunkan $\mathrm{pH}$ daging sehingga kualitas daging menjadi baik.

Hasil penelitian yang dilaporkan oleh Malelak et al. (2015) dengan menggunakan ekstrak jeruk nipis pada $s e^{\prime} i$ sapi diperoleh nilai $\mathrm{pH}$ berkisar antara 5,50-5,63, dan nilai $\mathrm{pH}$ pada penelitian ini adalah 5,40-6,37. Walaupun nilai $\mathrm{pH}$ pada penelitian ini berkisar lebih tinggi $\mathrm{pH}$ daging se' $i$ menggunakan ekstrak jeruk nipis namun menurut Badan Standar Nasional (1992) nilai $\mathrm{pH}$ yang dianjurkan untuk produk makanan terutama daging sapi adalah 5,0-7,0. Hal ini menggambarkan bahwa $\mathrm{pH}$ daging se' $i$ sapi tidak tergolong $\mathrm{pH}$ asam, ini diduga karena belimbing 
Tabel 1. Rataan nilai $\mathrm{pH}$ daging $s e^{\prime} i$ sapi menggunakan buah belimbing wuluh kering matahari dan lama penyimpanan yang berbeda

\begin{tabular}{ccccc}
\hline Lama penyimpanan & \multicolumn{4}{c}{ Level Belimbing Wuluh kering matahari \% } \\
\cline { 2 - 5 } (hari) & 0 & 1,5 & 3 & 4,5 \\
\hline 7 & $6,37 \pm 0,06^{\mathrm{a}}$ & $6,23 \pm 0,06^{\mathrm{ce}}$ & $5,97 \pm 0,06^{\mathrm{cg}}$ & $5,83 \pm 0,06^{\mathrm{c}}$ \\
14 & $6,07 \pm 0,12^{\text {aeg }}$ & $5,90 \pm 0,10^{\text {bc }}$ & $5,63 \pm 0,06^{\mathrm{b}}$ & $5,57 \pm 0,12^{\text {cfik }}$ \\
21 & $6,07 \pm 0,12^{\text {bce }}$ & $5,87 \pm 0,15^{\mathrm{f}}$ & $5,57 \pm 0,06^{\text {fhj }}$ & $5,43 \pm 0,06^{\mathrm{hjk}}$ \\
28 & $5,83 \pm 0,15^{\text {bei }}$ & $5,70 \pm 0,10^{\mathrm{fj}}$ & $5,50 \pm 0,10^{\mathrm{h}}$ & $5,40 \pm 0,10^{\mathrm{h}}$ \\
\hline
\end{tabular}

Superskrip pada baris dan kolom yang sama menunjukkan adanya perbedaan yang sangat nyata $(\mathrm{P}<0,01)$

wuluh mempunyai kandungan bioaktif asam-asam organik yang bisa mempertahankan $\mathrm{pH}$ daging se'i.

\section{Oksidasi Lemak (TBA mg malonaldehid/kg)}

Rataan nilai Thiobarbituric Acid (TBA) daging $s e^{\prime} i$ dapat dilihat pada pada Tabel 2. Hasil analisis statistik menunjukan bahwa level buah belimbing wuluh kering matahari dan lama penyimpanan berpengaruh sangat nyata $(\mathrm{P}<0,01)$ terhadap laju oksidasi lemak. Sedangkan interaksi antara level pemberian buah belimbing wuluh kering matahari dengan waktu lama penyimpanan menunjukan perbedaan nyata $(\mathrm{P}<0,05)$.

Interaksi antara faktor pemberian buah belimbing wuluh kering matahari dan faktor lama penyimpanan menurunkan laju oksidasi lemak pada daging se'i, rataan angka Thiobarbituric Acid tertinggi diperoleh pada perlakuan kontrol $0 \%$ pada lama penyimpanan hari ke $28(14,48 \mathrm{mg}$ malonaldehid $/ \mathrm{kg}$ ) dan terendah pada perlakuan $4,5 \%$ pada lama penyimpanan hari ke $7(2,75 \mathrm{mg}$ malonaldehid $/ \mathrm{kg}$ ). Nilai TBA daging se' $i$ tertinggi pada kontrol $0 \%$ dan cenderung menurun setelah pemberian perlakuan level 1,5, 3\%, dan 4,5\%. Berdasarkan Tabel 2. dapat dilihat bahwa peningkatan nilai TBA pada daging se' $i$ sapi yang tidak diberi perlakuan level kontrol $0 \%$ peningkatan laju oksidasi lemak lebih cepat dibandingkan yang diberi perlakuan buah belimbing wuluh kering matahari dengan level pemberian $1,5 \%, 3 \%$ dan $4,5 \%$ yang mengalami penurunan selama penyimpanan.
Hal ini disebabkan karena pada level kontrol $0 \%$ tidak terdapat peran antioksidan yang dapat menghambat laju oksidasi lemak selama masa simpan yang diberi buah belimbing wuluh. Semakin tinggi pemberian level semakin menekan laju oksidasi lemak, ini menunjukkan adanya peran antioksidan yang terdapat dalam buah belimbing wuluh dimana kandungan antioksidan pada buah belimbing wuluh terutama flavonoid berperan penting dalam menekan laju oksidasi lemak, fauzi et al., (2016) melaporkan sesuai dengan hasil penelitian uji fitokimia secara kuantitatif senyawa flavonoid dimana semakin tinggi kandungan senyawa antioksidan maka semakin besar kemampuan dalam menghambat proses oksidasi. Menurut Swarna et al., (2013) semakin tinggi kandungan total fenol dan flavonoid pada antioksidan maka semakin tinggi pula gugus hidroksilnya. Adanya gugus hidroksil dalam molekul akan meningkatkan kapasitas antiradikal yang menakan reaksi oksidasi.

Pokorny et al. (2001) dan Valencia et al. (2006) melaporkan bahwa senyawa fenol berfungsi sebagai antioksidan dan dapat mengurangi proses oksidasi asam lemak tak jenuh pada produk dengan penghambat pembentukan hidroperoksida. Pada umumnya, lemak dalam daging terdiri dari trigliserida, fosfolipid, kolesterol, dan vitamin yang larut dalam lemak. Menurut Shah et al. (2014) asam lemak dalam trigliserida terdiri dari asam lemak jenuh dan tidak jenuh, ketika daging sapi disimpan ikatan rangkap dari asam lemak tak jenuh berubah menjadi asam lemak rantai pendek, aldehide, atau keton yang menyebabkan

Tabel 2. Rataan nilai TBA (mg malonaldehid/kg) daging se' $i$ sapi menggunakan buah belimbing wuluh kering matahari dan lama penyimpanan yang berbeda

\begin{tabular}{ccccc}
\hline Lama penyimpanan & \multicolumn{4}{c}{ Level Belimbing Wuluh kering matahari \% } \\
\cline { 2 - 5 } (hari) & 0 & 1,5 & 3 & 4,5 \\
\hline 7 & $6,41 \pm 0,01^{\mathrm{a}}$ & $4,62 \pm 0,01^{\mathrm{e}}$ & $3,53 \pm 0,01^{\mathrm{i}}$ & $2,75 \pm 0,02^{\mathrm{m}}$ \\
14 & $8,18 \pm 0,01^{\mathrm{b}}$ & $7,87 \pm 0,01^{\mathrm{f}}$ & $6,57 \pm 0,02^{\mathrm{j}}$ & $4,34 \pm 0,02^{\mathrm{n}}$ \\
21 & $11,86 \pm 0,01^{\mathrm{c}}$ & $9,39 \pm 0,01^{\mathrm{g}}$ & $6,97 \pm 0,01^{\mathrm{k}}$ & $5,19 \pm 0,02^{\mathrm{o}}$ \\
28 & $14,48 \pm 0,07^{\mathrm{d}}$ & $10,41 \pm 0,04^{\mathrm{h}}$ & $7,99 \pm 0,08^{1}$ & $5,49 \pm 0,04^{\mathrm{p}}$ \\
\hline
\end{tabular}

Superskrip pada baris dan kolom yang sama menunjukkan adanya perbedaan yang sangat nyata $(\mathrm{P}<0,01)$ 
tengik, sehingga dalam pengolahan antioksidan biasanya ditambahkan mengurangi laju oksidasi lemak.

\section{Aktivitas antioksidan (DPPH)}

Rataan nilai Aktivitas Antioksidan daging se' $i$ dapat dilihat pada pada Tabel 3. Hasil statistik menunjukan bahwa level buah belimbing wuluh kering matahari dan lama penyimpanan berpengaruh sangat nyata $(\mathrm{P}<0,01)$ mempengaruhi nilai aktivitas antioksidan se'i. Sedangakan interaksi antara perlakuan level pemberian buah belimbing wuluh kering matahari dengan waktu lama penyimpanan menunjukan perbedaan nyata $(\mathrm{P}<0,05)$.

Tabel 3. Rataan nilai Aktivitas Antioksidan daging se'i sapi menggunakan buah belimbing wuluh kering matahari dan lama penyimpanan yang berbeda.

\begin{tabular}{ccccc}
\hline Lama penyimpanan & \multicolumn{4}{c}{ Level Belimbing kering matahari \% } \\
\cline { 2 - 5 } (hari) & 0 & 1,5 & 3 & 4,5 \\
\hline 7 & $26,74 \pm 0,17^{\mathrm{a}}$ & $37,88 \pm 0,11^{\mathrm{e}}$ & $67,49 \pm 0,11^{\mathrm{i}}$ & $80,56 \pm 0,11^{\mathrm{m}}$ \\
14 & $23,91 \pm 0,11^{\mathrm{b}}$ & $34,49 \pm 0,28^{\mathrm{f}}$ & $65,14 \pm 0,11^{\mathrm{j}}$ & $78,88 \pm 0,11^{\mathrm{n}}$ \\
21 & $20,09 \pm 0,30^{\mathrm{c}}$ & $30,77 \pm 0,23^{\mathrm{g}}$ & $61,73 \pm 0,24^{\mathrm{k}}$ & $76,69 \pm 0,23^{\mathrm{o}}$ \\
28 & $16,00 \pm 0,24^{\mathrm{d}}$ & $29,81 \pm 0,18^{\mathrm{h}}$ & $61,31 \pm 0,23^{1}$ & $75,74 \pm 0,18^{\mathrm{p}}$ \\
\hline
\end{tabular}

Superskrip pada baris dan kolom yang sama menunjukkan adanya perbedaan yang sangat nyata $(\mathrm{P}<0,01)$

Interaksi antara faktor pemberian buah belimbing wuluh kering matahari dan faktor lama penyimpanan meningkatkan aktivitas antioksidan pada daging $s e^{\prime} i$, rataan angka tertinggi diperoleh pada perlakuan level $4,5 \%$ pada lama penyimpanan hari ke hari ke $7(80,56 \%)$ dan terendah pada perlakuan level kontrol $0 \%$ pada lama penyimpanan hari ke $28(16,00 \%)$. Nilai aktivitas antioksidan meningkat seiring dengan meningkatnya penambahan kosentrasi perlakuan dikarenakan semakin banyak senyawa antioksidan pada kosentrasi yang menghambat radikal bebas DPPH. Hal ini menunjukan bahwa antioksidan yang tinggi pada buah belimbing wuluh bekerja untuk mengikat radikal bebas. Nilai aktivitas antioksidan meningkat seiring dengan meningkatnya jumlah pemberian level buah belimbing wuluh kering matahari dikarenakan semakin banyak senyawa antioksidan pada perlakuan tersebut yang dapat menghambat radikal bebas, adapun kandungan yang termasuk antioksidan didalam buah belimbing wuluh yaitu vitamin A, C, beta-karoten dan flavonoid (Gill et al., 2002).

Hal ini juga sesuai dengan pendapat Winarsi (2007) yang mengatakan bahwa antioksidan merupakan senyawa yang dapat menghambat terjadinya reaksi oksidasi, dengan mengikat radikal bebas dan molekul yang sangat aktif. Menurut Middleton et al., (2000), flavonoid merupakan senyawa aktif yang termasuk dalam jenis intermediet antioksidan yang berperan sebagai antioksidan hidrofilik dan lipofilik. Flavonoid merupakan senyawa yang berperan sebagai antioksidan.

\section{Total plate count (TPC)}

Rataan nilai dapat dilihat pada tabel 4 . Hasil statistik menunjukan bahwa penggunaan level buah belimbing wuluh kering matahari dan lama penyimpanan berpengaruh sangat nyata $(\mathrm{P}<0,01)$ mempengaruhi TPC daging se'i. Interaksi antara perlakuan level pemberian buah belimbing wuluh kering matahari dengan waktu lama penyimpanan menunjukan perbedaan nyata $(\mathrm{P}<0,05)$. Interaksi antara faktor pemberian buah belimbing wuluh kering matahari dan faktor lama penyimpanan memperlihatkan pemberian level kontrol $0 \%$ sampai $4,5 \%$ terjadi penurunan nilai TPC seiring peningkatan pemberian level belimbing wuluh kering matahari.

Tabel 4. Rataan TPC (log cfu/g) daging se'i sapi menggunakan buah belimbing wuluh kering matahari dan lama penyimpanan yang berbeda

\begin{tabular}{ccccc}
\hline \multirow{2}{*}{$\begin{array}{c}\text { Lama penyimpanan } \\
\text { (hari) }\end{array}$} & 0 & \multicolumn{4}{c}{ Level Belimbing kering matahari \% } \\
\cline { 2 - 5 } & $0,83 \pm 0,04^{\mathrm{ag}}$ & $0,73 \pm 0,03^{\mathrm{e}}$ & $0,67 \pm 0,02^{\mathrm{f}}$ & $0,63 \pm 0,02^{\mathrm{h}}$ \\
\hline 7 & $0,91 \pm 0,02^{\mathrm{b}}$ & $0,80 \pm 0,02^{\mathrm{a}}$ & $0,75 \pm 0,02^{\mathrm{ag}}$ & $0,66 \pm 0,03^{\mathrm{e}}$ \\
21 & $0,96 \pm 0,03^{\mathrm{c}}$ & $0,86 \pm 0,02^{\mathrm{b}}$ & $0,81 \pm 0,02^{\mathrm{a}}$ & $0,74 \pm 0,02^{\mathrm{ag}}$ \\
28 & $1,12 \pm 0,04^{\mathrm{d}}$ & $0,92 \pm 0,01^{\mathrm{d}}$ & $0,83 \pm 0,02^{\mathrm{b}}$ & $0,75 \pm 0,02^{\mathrm{b}}$ \\
\hline
\end{tabular}

Superskrip pada baris dan kolom yang sama menunjukkan adanya perbedaan yang sangat nyata $(\mathrm{P}<0,01)$ 
Pada level kontrol $0 \%$ pada lama penyimpanan hari ke 28 terjadi peningkatan nilai TPC sebesar $1,12 \log \mathrm{cfu} / \mathrm{g}$.Hal ini menunjukkan bahwa tanpa pemberian belimbing wuluh kering matahari tidak ada senyawa antibakteri pada daging se'i. Sedangkan pemberian level $1,5 \%, 3 \%$ dan $4,5 \%$ cukup efektif untuk menghambat pertumbuhan bakteri pada daging $s e^{\prime} i$ selama penyimpanan. Hai ini dilihat pada penurunan nilai TPC pada setiap perlakuan level pemberian buah belimbing wuluh kering matahari. Efektivitas belimbing wuluh kering matahari dapat menghambat pertumbuhan bakteri, karena mengandung senyawa bioaktif yang memiliki kemampuan untuk menghambat pertumbuhan bakteri, seperti senyawa tanin yang mampu mengganggu membrane sel bakteri. Buah belimbing wuluh mengandung flavonoid dan tanin yang merupakan senyawa antibakteri terbaik dari buah belimbing wuluh, senyawa aktif flavonoid memiliki beberapa mekanisme dalam menghambat pertumbuhan bakteri, selain itu senyawa flavonoid memiliki sifat kimia yang asam yang mampu menghambat pertumbuhan bakteri sehingga dapat menekan jumlah koloni bakteri (Black dan Jacob 1993; Robinson 1995; Pelczar 2008).

Mekanisme kerja tanin sebagai antibakteri adalah menghambat enzim reverse transkriptase sehingga sel bakteri tidak dapat terbentuk. Tanin memiliki kemampuan dalam menghambat pertumbuhan bakteri, menurut Marlin et al. (2015) tanin juga mempunyai sifat dapat mengekrutkan membran sel sehingga mengganggu jaringan sel bakteri.

\section{KESIMPULAN}

Hasil dari penelitian ini menunjukan bahwa interaksi antara faktor buah belimbing wuluh kering matahari dan faktor lama penyimpanan berpengaruh nyata $(\mathrm{P}<0,05)$ terhadap $\mathrm{pH}$, oksidasi lemak (TBA), aktivitas antioksidan, total plate count (TPC). Level pemberian buah belimbing wuluh kering matahari 4,5\% memberikan hasil tertinggi pada aktivitas antioksidan, dan nilai terendah pada $\mathrm{pH}$, oksidasi lemak (TBA) dan total plate count (TPC).

\section{DAFTAR PUSTAKA}

Ashari S. 1995. Hortikultura Aspek Budaya. UIPress, Jakarta.

BSN. Badan Standardisasi Nasional. 1992. 012891 :1992 Standard Nasional Indonesia "Cara Uji Makanan dan Minuman"
BSN. Badan Standardisasi Nasional. 2008. SNI 2897:2008 tentang Metode Pengujian Cemaran Mikroba dalam Daging, Telur dan Susu, serta Hasil Olahannya. Departemen Pertanian, Jakarta.

Buckle KA, Edwards, RA, Fleet GH, Wotton M. 1987. Ilmu Pangan. Penerjemah Hari Purnomo dan Adiono. Universitas Indonesia Press. Jakarta.

Departemen Kesehatan RI. 1995. Daftar Komposisi Zat Gizi Pangan Indonesia. Departemen Kesehatan RI, Indonesia, Departemen Kesehatan, Direktorat Jenderal Pembinaan Kesehatan Masyarakat Daftar Komposisi Zat Gizi Pangan Indonesia, Jakarta.

Fauzi A, Surti T, Rianingsih L. 2016. Efektivitas Daun Teh (Camellia Sinensis) Sebagai Antioksidan Pada Fillet Ikan Bandeng (Chanos Chanos Forsk.) Selama Penyimpanan Dingin. J. Peng. \& Biotek. Hasil Pi. 5(4): 1-10.

Hutasoit, K., I.G.K. Suarjana, I.K. Suada. 2013. Kualitas Daging Se'i Sapi di Kota Kupang Ditinjau dari Jumlah Bakteri Coliform dan Kadar Air. Indonesia Medicus Veterinus. 2(3): 248-260.

Jaelani, A., S. Dharmawati, B. Noor. 2016. Pengaruh Lama Penyimpanan Daging Itik Alabio dalam Refrigerator terhadap Kualitas Mikrobiologi, $\mathrm{pH}$ dan Organoleptik. Ziraa'ah 41(1): 145-155.

Kosim, A. 2015. Sifat Fisik dan Aktivitas Antioksi dan Dendeng Daging Sapi dengan Penambahan Stroberi (Fragaria ananassa) Sebagai Bahan Curing. Skripsi. Fapet. IPB. Bogor.

Malelak ,G.E.M., G.M. Sipahelut, I.G.N. Jelantik, M.R.D. Ratu, H.J.D. Lalel. 2015 Characteristics of Se'i (Rotenesse Smoked Meat) Treated with Coconut Shell Liquid Smoked and Citrus aurantifolia Extract. Media Peternakan 38 (2):89-94.

Malelak, G.E.M. 2010. Se'i (Daging Asap Khas Timor). Penerbit Lamalera, Jakarta.

Middleton, E. Jr, C. Kandaswami, T.C. Theoharides. 2000. The effects of plant flavonoids on mammalian cells: implications for inflammation, heart Complement Alternative Medicine 11(48): $1-9$. 
Oktasari, R., I. Diasari, S. Susilawati. 2020. Pengaruh lama perendaman dalam berbagai kosentrasi sari buah asam jawa (Tamarindus Indika L) terhadap whe dan $\mathrm{pH}$ daging kalkun. Jurnal Rekasatwa Peternakan. 3(1): 84-88.

Peraturan Pemerintah RI No 28 Tahun 2004. Http://Pengertianahli.Com Pengertian Pangan dan Jenis-Jenis Pangan. Html. Diakses Pada Senin 22 April 2019.

Pinem. 2004. Rancang Bangun Alat Pengeringan Ikan Teri Kapasitas $12 \mathrm{~kg} / \mathrm{Jam}$. Staf Pengajar Jurusan Teknik Mesin. Politeknik Negeri Malang. Jurnal Teknik Simetrika 3:249-253.

Pradana, H.A., B. Muwakhid, I. Dinasari. 2020. Pengaruh Konsentrasi Sari Belimbing Wuluh (Averrhoa bilimbi L) dan Lama Perendaman Terhadap $\mathrm{pH}$ dan WHC Pada Daging Kalkun Afkir. Jurnal Dinamika Rekasatwa 3(2): 73-78.

Shah, M.A., S.J.D. Bosco, and S.A. Mir. 2014. Plant extracts as natural antioxidants in meat and meat products. Meat Sci. 98: 2133.

Sudarmadji, S., B. Haryono, Suhardi. 1997. Analisis Bahan Makanan dan Pertanian. Penerbit Liberty kerjasama dengan pusat Antar Universitas Pangan dan Gizi Universitas Gadjah Mada, Yogyakarta.
Suhartono, E., Fujiati, I. Aflanie. 2002. Oxygen toxicity by radiation and effect of glutamic piruvat transamine (GPT) activity rat plasma after vitamin C treatment, Diajukan pada International seminar on Environmental Chemistry and Toxicology, Yogyakarta.

Sulistyani, W.I., M. Sulwana, W.F.D, Rahmawati, N. Cahyaningtyas, C.N. Mahardika. 2017. Pengaruh Sari Belimbing Wuluh (Averrhoa bilimbi L) terhadap Daya Hambat Bakteri Staphylococcus aureus. Jurnal Riset Kesehatan 6 (2):62-65.

Swarna, J., T.S. Lokeswari, M. Smita and D. Ravindhran. 2013. Characterisation and Determination of in Vitro Antioxidant Potential of Betalains from Talinium triangulare (Jacq.) Wild. Food Chemistry, 141: 4382-4390.

Valencia, I., D. Ansorena, and I. Astiasaran. 2006. Stability of Linseed Oil and Antioxidants Containing DRY fermented Sausages: A Study of The Lipid Fraction During Different Storage Conditions, Journal Meat Science 73: 269-277.

Winarsi, H. 2007. Antioksidan Alami dan Radikal Bebas: Potensi dan Aplikasinya dalam Kesehatan. Kanisius, Yogyakarta.

Yen, G. C, H. Y. Chen. 1994. Antioxidant and Pro-Oxidant Effect of Various Tea Extracts. J. Agric. Food. Chem. 45 (1): 30- 4. 